\title{
Clinical and angiographic predictors in primary percutaneous intervention
}

\author{
Pavel Platon', Carmen Ginghina ${ }^{1,2}$
}

\begin{abstract}
Percutaneous coronary intervention $(\mathrm{PCl})$ in patients presenting with acute myocardial infarction with ST segment elevation (STEMI) is the standard treatment according to the current European Society of Cardiology Guidelines. Certain aspects of therapy remain under debate, as periodic changes in the guidelines are enabled by new and thorough research. Objectives - We aimed to evaluate clinical and angiographic prognostic factors in patients presenting with acute STEMI treated with primary PCI. Methods - Demographical, clinical and procedural parameters were retrospectively analysed for 303 consecutive STEMI patients successfully treated with primary PCl. Short-term and long-term outcomes were evaluated. Results - Mean follow-up period was $18 \pm 12$ months. The studied endpoints were mortality, major adverse cardiac events (MACEs) and left ventricular ejection fraction (LVEF). At admission TIMI flow 0 or I was found in 233 (76.9\%) of patients and was associated with increased mortality and MACE. Of the studied population, 232 (76.6\%) patients had MBG 0 and 52 (17.2\%) of patients had MBG I. In these subgroups of patients mortality was higher than in those with MBG of 2 or 3 ( $p<0.05)$. An increase in TIMI flow and MBG score of at least 2 points after successful reperfusion was correlated with decreased mortality and improvement in the LVEF $(p<0.05) .46(15.2 \%)$ of patients presented with atrial fibrillation while 277 ( $91.4 \%$ ) of patients presented with hypertension at admission. These clinical characteristics were associated with negative survival in STEMI patients $(p<0.05)$. Conclusion - TIMI flow grade and MBG were strong predictors for mortality and cardiovascular events in STEMI patients undergoing primary coronary artery angioplasty. Atrial fibrillation and presence of hypertension predict survival in STEMI patients treated with primary PCI.
\end{abstract}

Keywords: Acute ST elevation myocardial infarction, percutaneous coronary intervention, angiography, TIMI flow score, myocardial blush grade.

Rezumat: Angioplastia coronariană percutanată primară reprezintă tratamentul de elecție pentru pacienții cu infarct miocardic acut cu supradenivelare de segment ST conform ghidurilor actuale de management elaborate de către Societatea Europeană de Cardiologie. Aceste ghiduri sunt revizuite periodic, modificările indicațiilor actuale fiind susținute de noi cercetări în domeniu. Obiective - Acest studiu și-a propus evaluarea factorilor clinici și angiografici de prognostic pentru pacienții cu infarct miocardic acut cu supradenivelare de segment ST (STEMI) tratați prin angioplastie coronariană percutanată primară. Metode - Parametrii demografici, clinici și procedurali au fost analizați retrospectiv pentru 303 pacienți consecutivi cu STEMI trataţi în clinica noastră prin angioplastie coronariană primară. Au fost urmărite complicațiile, mortalitatea intraspitalicească precum și mortalitatea pe termen lung. Rezultate - Perioada medie de urmărire a fost de $18 \pm$ 12 luni. Obiectivele primare studiate au fost mortalitatea, evenimentele cardiovasculare și fracția de ejecție a ventriculului stâng. $232(76,6 \%)$ dintre pacienți au avut flux TIMI 0 sau I, această caracteristică fiind asociată cu o creștere a mortalității și a evenimentelor cardiovasculare adverse ( $p<0,05)$. 232 (76,6\%) dintre pacienți au avut blush miocardic MBG 0 sau I, aceste grupe de pacienți fiind asociate cu o creștere a mortalității față de pacienții cu MBG 2 sau 3 ( $p<0,05)$. Dintre pacienții incluși în studiu, 46 (15,2\%) au avut fibrilație atrială, iar 277 (9I,4\%) au fost hipertensivi, caracteristice clinice ce s-au asociat cu mortalitate crescută $(p<0,05)$. Concluzii - Fluxul TIMI și blush-ul miocardic MBG au fost predictori importanți pentru mortalitate și evenimente cardiovasculare adverse la pacienții cu STEMI ce beneficiază de angioplastie coronariană percutanată primară. Prezența fibrilației atriale și a hipertensiunii arteriale la momentul internării sunt predictori negativi pentru supraviețuire.

Cuvinte cheie: Infarct miocardic acut cu supradenivelare de segment ST, angioplastie coronariană percutanată primară, flux TIMI, grad de blush miocardic.

\footnotetext{
' „Prof. Dr. C.C. Iliescu” Emergency Institute for Cardiovascular Diseases, Bucharest, Romania

${ }^{2}$ "Carol Davila” University of Medicine and Pharmacy, Bucharest, Romania
}

\section{Contact address:}

Pavel Platon, MD

„Prof. Dr. C.C. Iliescu” Emergency Institute for Cardiovascular

Diseases, Bucharest, Romania.

E-mail: pavelplaton@yahoo.com 


\section{INTRODUCTION}

Acute coronary syndromes represent an important healthcare problem in the developing countries'. As the life expectancy in the general population increases, so does the prevalence of coronary artery disease ${ }^{2}$. The most dangerous phenotype of this disease is represented by acute coronary syndromes. The mainstay of therapy for this group of patients equates to obtaining myocardial reperfusion ${ }^{3}$. The gold standard myocardial reperfusion is achieved by primary percutaneous intervention that is done as fast as possible ${ }^{4}$. This treatment is associated with low rates of mortality and MACEs compared to medical therapy and fibrinolysis ${ }^{5}$. Despite our current knowledge and use of state of the art percutaneous coronary intervention, an important number of cases have little or no benefit from the procedure even though angiographic epicardic coronary reperfusion has been succesfully achieved $^{6}$. Numerous studies succeeded to find accurate clinical and angiographic predictors for mortality or softer endpoints in patients presenting with acute coronary syndromes ${ }^{7}$. Left ventricular ejection fraction, NYHA functional class, Killip class, TIMI flow score are well established elements which influence the evaluation and prognosis in these patients ${ }^{8}$.

\section{METHODS}

\section{Study population}

We performed a single centre retrospective trial at "Prof. Dr. C.C. Iliescu" Institute for Emergency Cardiovascular Diseases in Bucharest. A total of 1895 STEMI patients were admitted in our hospital between January 2015 and December 2016. We selected a subgroup of 324 patients in which the procedure was performed by the same operator with primary $\mathrm{PCl}$ within 24 hours from symptom onset. Inclusion criteria were the presence of ischaemic symptoms, ECG changes of acute STEMI according to current European Guidelines and interventional procedure being performed by the same physician. Exclusion criteria were represented by lack of need for an interventional procedure (angiogram not suited for coronary intervention), successful thrombolysis, inadequate angiographic images or lack of follow-up.

Of the 324 patients, 21 were excluded due to the criteria described ( 9 not suited for intervention, 4 with unusable angiography films and 8 with no follow-up).

The study protocol was reviewed and approved by the Ethics and Institutional Review Board of our clinic. Informed consent was obtained for every patient included in this trial.

\section{Variables}

Collected variables consisted of demographic data, clinical characteristics, pre-, post- and procedural angiographic parameters. The demographic and clinical profile consisted of: gender, age, history of hypertension, dyslipidaemia, obesity $\left(\mathrm{BMI}>30 \mathrm{~kg} / \mathrm{m}^{2}\right)$, diabetes mellitus, smoker status, history of atrial fibrillation, angina, coronary artery syndrome, heart failure, peripheral arterial and cerebrovascular disease. Admission profile included: time from symptom onset, Killip class, ejection fraction, infarcted territory, presence of cardiogenic shock, severity of mitral regurgitation, biological markers (haemoglobin, creatinine, high sensitivity troponin, NTproBNP, CK and CK-MB). Chronic kidney disease was evaluated using estimated glomerular filtration rate (eGFR) according to the National Kidney Foundation classification'. Amongst the procedural characteristics recorded were: vascular access site, culprit artery, culprit lesion length, vessel diameter, number of affected vessels, grade of stenosis, presence of vessel calcification, number, diameter and length of stents which were used, presence of thrombus, glycoprotein Ilb/llla inhibitors, need for thromb aspiration and use of intra-aortic balloon pump. Dynamic parameters which were observed before and after the procedure were the thrombolysis in myocardial infarction (TIMI) flow grade and the myocardial blush grade (MBG).

All patients were pre-treated with double antiplatelet therapy (aspirin and a P2Y2 inhibitor) and heparin prior to cath-lab admission. Successful $\mathrm{PCl}$ procedure was defined as TIMI 3 flow and a reduction of the culprit lesion stenosis $<50 \%$.

Eligible patients were followed over a mean period of 4 years. Post-procedural events such as procedural complications, days of hospitalisation and in-hospital mortality were recorded. After discharge patients were followed up in our clinic at 6-12 months periods and long-term survival data were obtained in some cases through National System Health Records or by contacting the family.

\section{Angiography}

Angiography films were retrospectively analysed by the performing physician and another highly trained operator from our clinic with a $3^{\text {rd }}$ consultant being used in cases where there were important divergencies between evaluations. Thrombolysis in myocardial infarction (TIMI) flow was defined according to the grading system established for angiographic assessment of myocardial perfusion in myocardial infarction ${ }^{10}$. As 
such, this tool evaluates semi-quantitatively the coronary blood flow in 4 separate categories (TIMI flow 0 , I, 2 and 3). Myocardial blush grade (MBG) was defined according to the system developed by Van't Hof et al." as contrast filling in the distal coronary bed after passage through the epicardial vessel. This scoring system has 4 grades as follows: MBG 0 - no myocardial blush, MBG I - minimal myocardial blush, MBG 2 moderate myocardial blush and MBG 3 - normal myocardial blush. No automated techniques were used for the assessment of TIMI flow or myocardial blush. The angiographic parameters were evaluated across the same angiographic views in every patient: 2 views for the left system (LAO cranial and RAO caudal) and in one view for the right coronary artery (LAO). The assessing operators did not have acces to clinical data or post-procedural outcomes during the evaluation. An agreement existed between the 2 operators in 285 (94\%) of patients, for the remaining $6 \%$ an agreement was reached after consulting with a $3^{\text {rd }}$ operator. This method for evaluation of TIMI blood flow and myocardial blush grade was validated in several prior studies with good reproducibility and low inter- and intra-observer variability ${ }^{8}$. The guiding catheter was used for scale and dimension calibration.

The primary endpoint included cardiovascular mortality. Secondary endpoints included recurrent cardiovascular events (MACE), LVEF at discharge, need for reintervention, TIMI flow grade and MBG post-PCI.

\section{Statistical analysis}

Data were collected using an Excel spreadsheet and subsequently imported into IBM $^{\circledR}$ SPSS $^{\circledR}$ Statistics software version 25.0. Normal distribution of variables was assessed by Shapiro-Wilk test. Quantitative variables were expressed as mean \pm SD and compared using the Student t-test, Mann-Whitney $U$ test. Mortality risk was presented using Kaplan-Meier survival function and differences were tested using Log Rank test (univariate) and Cox regression (multivariate). Multivariate logistic regression analysis was used to identify predictive clinical and angiographic factors for outcomes. A p value of $<0.05$ was used to define statistical significance. No multiplicity adjustments were considered necessary.

\section{RESULTS}

A total of 303 patients were included in the study. Mean age for the studied population was $62.35 \pm$ I 3.69 (SD) years. 223 (73.6\%) were male.
Hypertension was present in 277 (9l.4\%) of patients, with $48.5 \%$ of patients having grade 3 hypertension (SBP > I $80 \mathrm{mmHg}$ ). Atrial fibrillation was present in 46 (15.2\%) of patients. The majority (89.1\%) of patients had dyslipidaemia while only $42.6 \%$ of them were obese. Diabetes was present in $29 \%$ of patients, with $3.6 \%$ of the patients being insulin dependent diabetics. I 64 (54\%) were active smokers, 69 (22.8\%) were former smokers and 70 (23.1\%) were non-smokers. $42 \%$ of the population had a history of angina, $8 \%$ had a history of acute coronary syndrome, $3.6 \%$ had prior $\mathrm{PCl}$ and $1.3 \%$ had prior CABG. Heart failure was present in $27.4 \%$ of patients at admission, the majority (68.7\%) of the patients were Killip class I.

\begin{tabular}{|c|c|c|}
\hline & Median & SD \\
\hline Age & 62.35 & 13.69 \\
\hline LVEF & $41.02 \%$ & $8.73 \%$ \\
\hline Hours from onset & 6.69 & 3.89 \\
\hline Haemoglobin & 14.27 & 1.69 \\
\hline Creatinine & 1.07 & 0.71 \\
\hline eGFR & 81.49 & 26.43 \\
\hline NTproBNP & 2683 & 310 \\
\hline hs-cTnl & 9.34 & 15.91 \\
\hline Follow-up (days) & 554.28 & 337.9 \\
\hline
\end{tabular}

Anterior myocardial infarction was observed in $38 \%$ of the patients, followed by inferior $(30 \%)$ and inferopostero-lateral (16.2\%) territories. Right ventricular infarction was present in $4.3 \%$ of the patients and was associated more frequently with inferior myocardial infarction. The main culprit artery was the left anterior descending artery in $44 \%$ of patients the right coronary artery in $40 \%$ of patients and the circumflex artery in $14.5 \%$ of patients. Significant thrombus burden was seen in $49.8 \%$ of patients and thromb aspiration technique was performed in $44.9 \%$ of patients.

Cardiogenic shock was present in 27 cases (9\%). Cardiogenic shock at presentation was associated with worse outcome and higher mortality. Mild mitral regurgitation was encountered in $44 \%$ of patients while severe mitral regurgitation was found in $21 \%$ of the studied population.

Femoral arterial access site was used in $92 \%$ of the cases and was associated with an increased complication rate. 


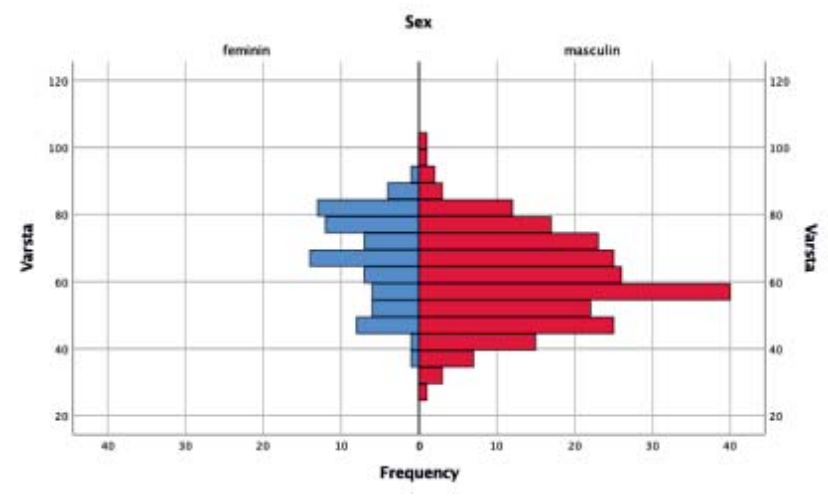

Figure I. Study population pyramid.

\begin{tabular}{|l|c|}
\hline \multicolumn{2}{|c|}{ Table 2. History of prior cardiovascular disease } \\
\hline & Frequency (\%) \\
\hline Angina & $127(4 I .91)$ \\
\hline ACS & $24(7.92)$ \\
\hline PCI & $11(3.63)$ \\
\hline CABG & $4(1.32)$ \\
\hline PAD & $12(3.96)$ \\
\hline CKD & $36(11.88)$ \\
\hline Stroke & $20(6.6)$ \\
\hline Heart failure & $83(27.39)$ \\
\hline Atrial Fibrillation & $46(15.2)$ \\
\hline
\end{tabular}

\begin{tabular}{|l|c|}
\hline \multicolumn{2}{|l|}{ Table 3. Cardiovascular risk factors } \\
\hline & Frequency (\%) \\
\hline Hypertension & $26(8.6)$ \\
Absent & $33(10.9)$ \\
Grade I & $97(32)$ \\
Grade 2 & $147(48.5)$ \\
Grade 3 & $270(89.1)$ \\
\hline Dyslipidaemia & \\
\hline Diabetes mellitus & $215(71.0)$ \\
Absent & $35(11.6)$ \\
No treatment (diet) & $42(13.9)$ \\
Oral AD & $11(3.6)$ \\
Insulin & \\
\hline Smoker status & $70(23.1)$ \\
Non-smoker & $69(22.8)$ \\
Former smoker & $164(54.1)$ \\
Active smoker &
\end{tabular}

Table 4. LV dysfunction at admission (mild: LVEF = 40-

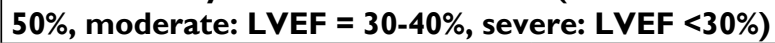

\begin{tabular}{|l|c|}
\hline & Frequency (\%) \\
\hline Normal LVEF & $73(24.1)$ \\
\hline Mild & $135(44.6)$ \\
\hline Soderate & $72(23.8)$ \\
\hline
\end{tabular}

Identification of factors for the selected endpoints was performed by executing univariate and multivariate logistic regression analysis.

There was no significant survival difference between women and men. Hypertension can predict different survival. Patients who did not have arterial hyper-

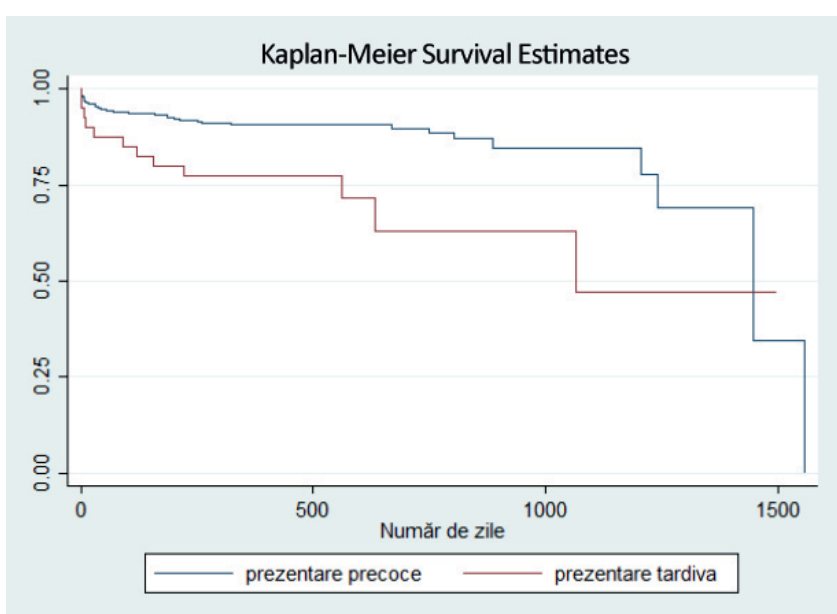

Figure 2. Difference in survival by time of presentation $(p=0.0018)$.

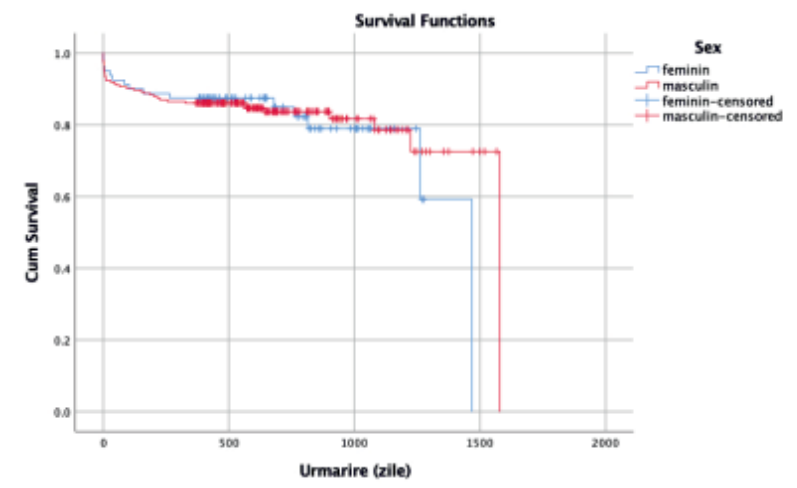

Figure 3. Difference in survival by gender $(p>0.05)$.

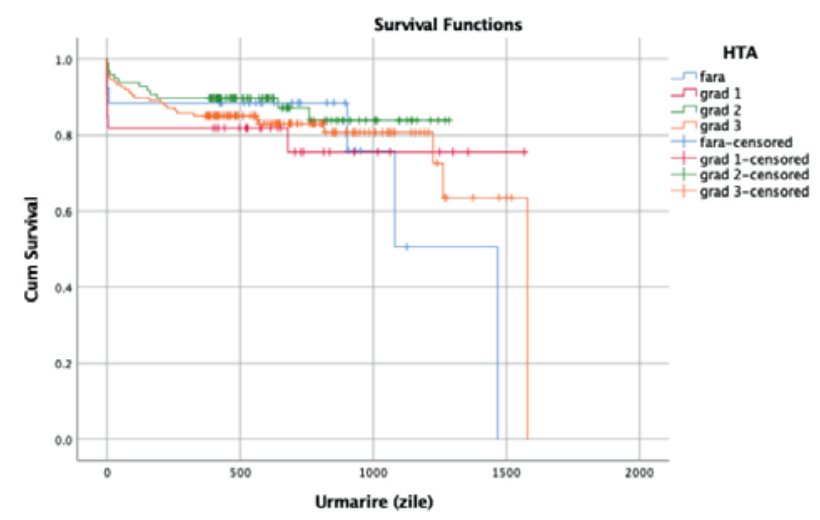

Figure 4. Difference in survival by the presence and grade of hypertension $(p<0.01)$.

tension on admission had a longer survival period and fewer MACEs during follow-up than patients which had grade 3 hypertension $(\mathrm{p}<0.0 \mathrm{I})$.

Atrial fibrillation was an important predictor for mortality and complications $(p<0.01)$. Higher rates of complications (increased bleeding) were observed in 


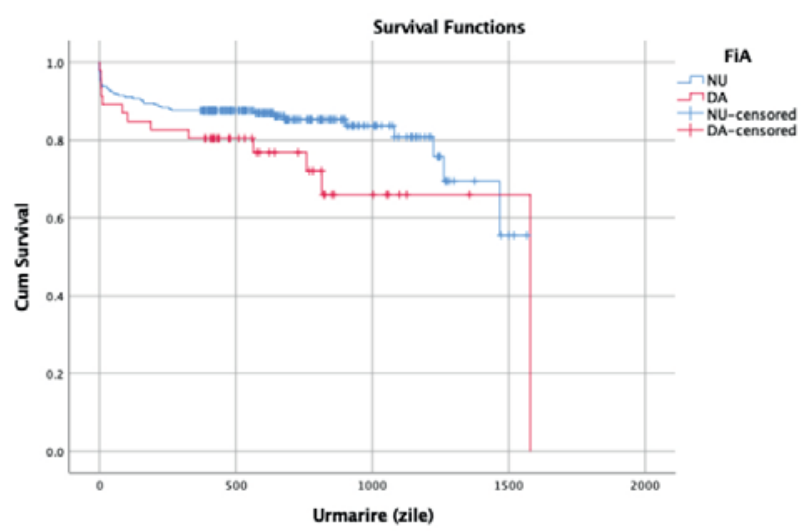

Figure 5. Difference in survival by the presence of atrial fibrillation $(p<0.05)$.

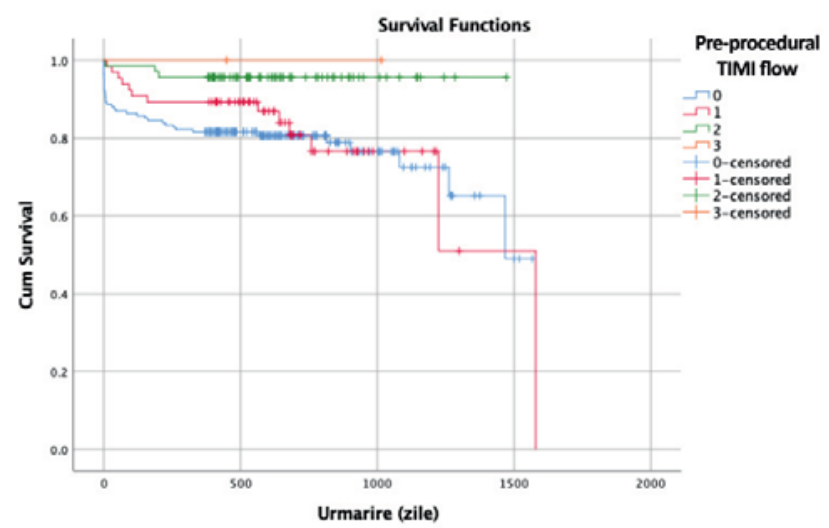

Figure 6. Difference in survival by pre-procedural TIMI flow $(p=0.023)$.

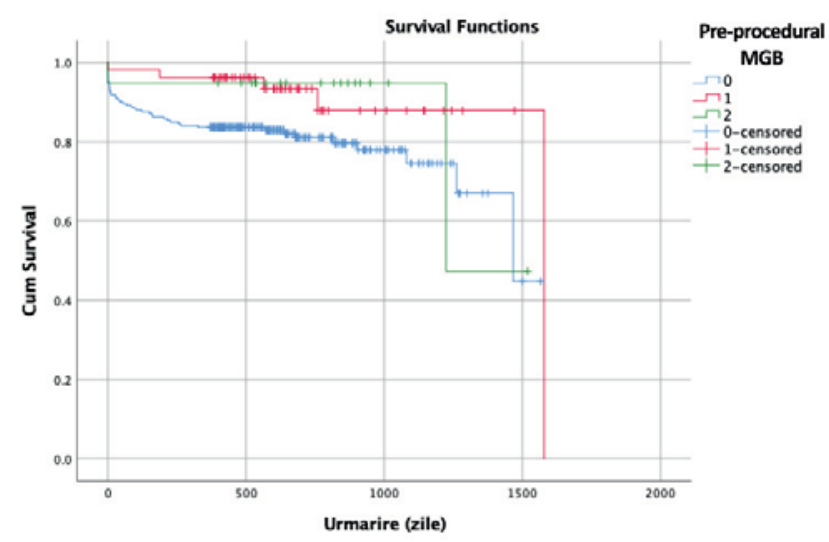

Figure 7. Difference in survival by the pre-procedural myocardial blush grade $(p=0.049)$.

this group of patients, probably associated with need for anticoagulation.

Patients with pre-procedural TIMI flow lower than 2 had higher mortality. This subgroup of patients had also more cardiovascular risk factors (more active smokers, higher grade of hypertension, higher rate of dyslipidaemia) and had more extensive coronary artery disease on angiographic evaluation. They had higher LV dysfunction on admission and more frequent involvement of the left descending anterior artery.

Patients presenting within more than 12 hours from onset of the symptoms showed significantly higher mortality during the 2 years follow-up, compared to those with early admission $(p=0.0018)$, as shown in Figure 2.

The survival curves showed a significantly higher risk of mortality in patients with pre-procedural myocardial blush grade lower than 2. MACEs free survival rate was significantly higher for patients with myocardial blush grade greater than 2 . No difference in survival was observed for patients in whom thromb aspiration was performed.

Figures 3-7 show the cumulative survival by gender, presence of atrial fibrillation, hypertension, TIMI flow and myocardial blush grade on admission. For the univariate analysis, all but gender show that they may predict survival (Log rank test). We have further tested if these can independently predict survival. Cox regression shows that all-cause death can be predicted by both TIMI flow and myocardial blush grade lower than 2 as well as increased age, having a diagnosis of hypertension or atrial fibrillation at admission.

\section{DISCUSSION}

STEMI treatment algorithms are constantly updated based on novel research. Defining key mortality predictors is a crucial area of current research.

The cardinal finding of our study demonstrates the important prognostic value of clinical and angiographic characteristics in acute STEMI patients treated with percutaneous coronary intervention.

As shown by other researchers, clinical aspects remain strong predictors of mortality in STEMI'2. Hypertension (predominantly grade 3 ), presence of shock and atrial fibrillation at admission were the most important factors for predicting survival and adverse cardiovascular events in our study.

While TIMI flow grade is a well established parameter in the current literature with strong correlation for death and MACEs ${ }^{13}$, myocardial blush grade lacks considerable research to back it up for use as a tool in evaluation of these patients. Although it is a more resource intensive technique that necessitates more time for acquisition and analysis of angiographic images, myocardial blush grade is useful for evaluating prognosis in patients with TIMI flow 3 . These patients 
have successful reperfusion with normal flow in the epicardial coronary artery, but some studies suggested that prognosis is different in this subgroup. One study demonstrated that MBG is related to TIMI flow and that myocardial perfusion can be inadequate (MBG of 0 or I) even when TIMI flow 3 is present ${ }^{14}$. As such, MBG can be a useful tool for evaluation of patients with poorer prognosis amongst those with TIMI 3 flow after reperfusion. In our study, pre and post-procedural myocardial blush grade was correlated TIMI flow, mitral regurgitation severity, mortality and MACEs.

\section{STUDY LIMITATIONS}

This study is a retrospective, unrandomized clinical study, so results are vulnerable to selection errors. It was performed in a single tertiary centre, with expertise in STEMI treatment and results should be validated in a large, multi-centercentre study. Another possible limitation of this analysis is the subjective method of blush quantification, operator and vendor dependent. Comparison with delayed-enhanced cardiac magnetic resonance assessment of microvascular obstruction could surpass this limitation in a future study.

\section{CONCLUSION}

In summary, our research showed that pre-procedural TIMI flow and myocardial blush grade were strong predictors for mortality in STEMI patients treated with primary $\mathrm{PCl}$. Atrial fibrillation and presence of hypertension at admission predict survival in STEMI patients treated with primary $\mathrm{PCl}$.

Conflict of interest: none declared.

\section{References}

I. Kumar A, Cannon CP. Acute coronary syndromes: Diagnosis and management, part I. Mayo Clin Proc. 2009;84(I0):917-938. doi:I0. 4065/84.10.917

2. The World Health Organization. The top ten causes of death fact sheet. http://www.who.int/mediacentre/factsheets/fs310/en/index. html. Published 2015.

3. Ibanez B, James S, Agewall S, et al. 20I7 ESC Guidelines for the management of acute myocardial infarction in patients presenting with ST-segment elevation. Eur Heart J. 2018;39(2): I I9-177. doi: I0.1093/ eurheartj/ehx393

4. Terkelsen CJ, Christiansen EH, Sørensen JT, et al. Primary $\mathrm{PCl}$ as the preferred reperfusion therapy in STEMI: it is a matter of time. Heart. 2009;95(5):362 LP - 369. doi:I0.I I36/hrt.2007.139493

5. Armstrong PW, Gershlick AH, Goldstein P, et al. Fibrinolysis or primary $\mathrm{PCl}$ in ST-segment elevation myocardial infarction. $\mathrm{N}$ Engl J Med. 20|3;368(I5): I379-I387. doi:I0.1056/NEJMoa I30I092

6. Ambrosio G, Weisman HF, Mannisi JA, Becker LC. Progressive impairment of regional myocardial perfusion after initial restoration of postischemic blood flow. Circulation. 1989;80(6): I846-186I. doi: 10. I I6I/0I.CIR.80.6.1846

7. Ashraf T, Khan MN, Afaque SM, et al. Clinical and procedural predictors and short-term survival of the patients with no reflow phenomenon after primary percutaneous coronary intervention. Int J Cardiol. 2019;(xxxx):7-II. doi:10.1016/j.ijcard.2019.07.067

8. Addala S, Grines CL, Dixon SR, et al. Predicting mortality in patients with ST-elevation myocardial infarction treated with primary percutaneous coronary intervention (PAMI risk score). Am J Cardiol. 2004;93(5):629-632. doi:10.1016/j.amjcard.2003.II.036

9. Evaluation D. Correction: National Kidney Foundation Practice Guidelines for Chronic Kidney Disease. Ann Intern Med. 2003; I39 (7):605. doi: 10.7326/0003-48|9-139-7-2003 I0070-00029

10. Appleby MA, Angeja BG, Dauterman K, Gibson CM. Angiographic assessment of myocardial perfusion: TIMI myocardial perfusion (TMP) grading system. Heart. 200I;86(5):485-486.

II. Van 't Hof AWJ, Liem A, Suryapranata H, Hoorntje JCA, De Boer MJ, Zijlstra F. Angiographic assessment of myocardial reperfusion in patients treated with primary angioplasty for acute myocardial infarction: Myocardial blush grade. Circulation. 1998;97(23):2302 2306. doi:I0.II6I/0I.CIR.97.23.2302

12. Zorbozan O, Cevik AA, Acar N, et al. Predictors of mortality in ST-elevation MI patients. Med (United States). 2018;97(9):I-5. doi:I0.1097/MD.0000000000010065

13. De Luca G, Parodi G, Sciagrà R, et al. Preprocedural TIMI flow and infarct size in STEMI undergoing primary angioplasty. J Thromb Thrombolysis. 20I4;38(I):8I-86. doi:I0.1007/s I I239-0I3-0977-x

14. Rasoul S, Dambrink JHE, Breeman A, Elvan A, Van 't Hof AWJ. The relation between myocardial blush grade and myocardial contrast echocardiography: Which one is a better predictor of myocardial damage? Netherlands Hear J. 2010; I8(I):25-30. 